\title{
Production rules down on the farm
}

\section{USDA's "payment-in-kind" programme has had a stunning - and expensive - success in getting farmers to grow less. Good research would have been a better investment.}

EIGHTY-TWO million acres of corn (maize), wheat, sorghum, rice, and cotton land are lying idle in the United States this year as a result of the most successful - and most expensive - acreage diversion programme attempted by the US Department of Agriculture (USDA) since the inception of such programmes during the New Deal. Preliminary estimates of the cost range from $\$ 20,000$ million upwards. And while the programme is by its own criteria a success - production dramatically reduced, commodity prices increased (December corn futures are now more than $\$ 3$ per bushel, up from less than $\$ 2$ last year) - it is hardly the sort of solution that either politics or economics will allow to be lasting. The pity is that so little funding is being channelled to fundamental solutions of the farmer's perennial plight of overproduction, low prices and unstable markets.

Agricultural research has deeper roots in the federal government than do any of the farm support programmes, and even the most general of policy objectives seems to leave research untouched. The land-grant colleges and state experimental stations, established a century ago, still form the backbone of US agricultural research. These institutions, traditionally focusing on local needs, have never really been subject to a coherent national policy. Their funding is set by a state-by-state allocation formula dating back to the days of their founding, and no national goals - or even scientific peer review - can alter that pattern of funding.

The diversity of the system, to be sure, together with its responsiveness to local problems, accounts for much of American agriculture's phenomenal success. Yet this was truer in the past than it is today. Rapid communication has eliminated some of the justification for 50 separate research institutions spread across the country. At the same time, the benefits to be gained from management improvements and technological application, which are of a fundamentally regional character, are shrinking compared with the potential benefits of a fundamental expansion of our understanding of plant genetics, to choose one obvious example.

The state-by-state system of agricultural research seems an anachronism, especially when contrasted with the way the $\mathrm{Na}$ tional Institutes of Health or the National Science Foundation operate. Even worse than the fact that agricultural research funds are doled out without regard to the scientific merits of the projects is the exclusion of non-land-grant universities from the system. Harvard, Stanford and Massachusetts Institute of Technology, to name a few universities that might contribute much to plant genetics, are not eligible to receive USDA research funds. The best molecular genetics students at these institutions have no good reason to choose plant sciences over medical sciences when they see where scholarships and traineeships are available; young researchers face a similar foregone choice.

A small programme of competitive, peer-reviewed grants has been run by USDA for five years, but it represents a drop in the ocean; $\$ 17$ million, compared with the $\$ 244$ million federal contribution to the land-grants. One is tempted to push the comparison further and cast an eye at the $\$ 20,000$ million to be spent this year on commodity price support. The comparison is in fact not unfair. Like all farm programmes since the New Deal, this year's "payment-in-kind" programme seeks to support commodity prices in exchange for (and,in part, by way of) decreased production. Farmers face increasing costs and inadequate prices; as "price-takers", they not infrequently face a market that will not pay them for the costs of production.

The lynchpin of the price support programmes for field crops is the Commodity Credit Corporation (CCC), one of the most successful and enduring of the New Deal initiatives. CCC offers farmers a loan for their crops; the farmers, in turn, pledge the crop as collateral. If the market price exceeds the loan price, the farmer sells his crop and repays the loan. If the market price drops below the loan price, he can choose to default on the loan, in effect selling the government his crop. In accepting the loan, the farmer agrees to set aside some percentage of his acreage.

CCC's stockpiles of commodities have been growing in recent years, and in a move to unload its stocks and, according to plan at least, save the government some money, farmers were of fered a different deal this year: in exchange for not planting large numbers of acres, they would receive a government payment in the commodity they would have planted. This payment-in-kind scheme went over so well that USDA is now encouraging farmers to grow wheat and voluntarily default on their CCC loans so that USDA will have enough wheat with which to pay farmers. USDA has requested $\$ 325$ million to buy this wheat which it needs to pay farmers not to grow wheat.

The emphasis in all of these support programmes is on the production side. Similarly, to the extent that goals in agricultural research are articulated, they too emphasize production. Missing is any consideration of the costs farmers face - and what really matters to farmers is not production, not even price per se, but profit margin. Rather than spend thousands of millions of dollars supporting prices, a modest investment might be contemplated in reducing costs. Plant genetics would not be a bad place to start. The possibility of engineering as much technology as possible into the genes of the seed is surely the most direct route to reduced input costs. And more efficient crop varieties and resistant varieties could make dramatic cuts in fertilizer and pesticide expenses.

Surely some of the $\$ 20,000$ million being poured into price supports can be more wisely invested in pursuit of long-term dividends. The $\$ 17$ million allocated for competitive grants in agriculture is an embarrassingly small investment in good science - especially when good science may hold the answer to the perennial public policy problem of keeping farms in business.

\section{Thatcher's man}

\section{The scientific adviser to the British Prime Minister may be too close for comfort.}

THE shape, if not the plans, of Mrs Thatcher's new government is now clear. Armed with a greatly increased majority from a slightly decreased proportion of the total votes cast, she has quickly disposed of those members of her past government who had publically argued for moderation along with those who had not noticeably argued for anything. One victim of the latter category is $\mathrm{Mr}$ William Shelton, who returns to the backbenches to make way for fewer, newer (see page 650) junior ministers to assist the unpopular, but retained, Sir Keith Joseph in the Department of Education and Science. Also retained, amongst other things to denationalize British Telecom, is Mr Kenneth Baker, Minister for Industry and Information Technology within the newly 